\title{
ORGANIZATION AND ANALYSIS OF RESULTS OF RESEARCH AND EXPERIMENTAL WORK ON FORMATION OF PROFESSIONAL COMPETENCE OF FUTURE EDUCATORS OF EDUCATORS
}

\author{
Tetyana Telychko ${ }^{1}$ \\ ${ }^{I}$ Teacher of preschool department, Humanities and Pedagogical College, Mukachevo State University, \\ Ukraine,e-mail: tmyzuka@gmail.com, ORCID: http://orcid.org/0000-0002-6916-2273
}

\begin{abstract}
The need to solve the problem of forming the professional competence of future educators of preschool education determined the purpose of the experimental work - the implementation of pedagogical conditions and structural and functional model of forming the professional competence of future educators of preschool education on the basis of interdisciplinary approach. The logic of experimental work (concretization of experimental procedures development) in the context of approbation of the developed structural-functional model of the studied phenomenon allowed to objectively assess its sufficiency and necessity for effective formation of professional competence of future educators in the context of expediently created, timely controlled pedagogical conditions. meaningful and integrative pedagogical possibilities of interdisciplinary approach.
\end{abstract}

The experiment is considered as a method of scientific knowledge, which consists in the purposeful study of any phenomenon of reality in controlled and controlled conditions. The experiment, acting as a criterion for the truth of scientific knowledge, was the basis for testing hypotheses and predictions of the theory. To solve the set tasks, a pedagogical experiment was chosen, which was conducted in three stages: ascertaining, formative, and final. The choice of method is explained by the fact that it is planned to compare the results of formation of professional competence of future educators of ZDO in traditional training of students and within the implementation and realization in the educational process of pedagogical conditions and structural-functional model of formation of professional competence of future educators of preschool institutions. . The structural organization of the pedagogical experiment included: organizational training, pre-experimental section, experimental training, final post-experimental section. The results of comparative studies of the formation of professional competence in future educators of preschool education institutions in the control and experimental groups are presented.

Keywords: professional competence, methods of competence assessment, pedagogical experiment, criteria, indicators, levels.

JEL Classification: I0; I20

Formulas: 0; fig.: 0; tabl.: 0; bibl.: 6

Introduction. In modern psychological and pedagogical research of domestic and foreign scientists the modernization of higher professional education on the basis of the competence approach is actualized [2, p. 68]. The formation of competencies of future professionals is the main goal and result of higher education. The specifics of pedagogical training - in a combination of pedagogical and special components of the disciplines of the curriculum, which, accordingly, is manifested in the formation of a block of pedagogical and special competencies [5, p. 37]. The study of the formation of professional competence of future educators of preschool education (PE) on the basis of an interdisciplinary approach necessitated an experimental test of the effectiveness of the developed structural and functional model that implements the pedagogical conditions for the formation of professional competence.

Aims. The purpose of the study is to analyze the dynamics of changes in the formation of professional competence of future educators of preschool education on 
the basis of an interdisciplinary approach during the formative pedagogical experiment.

The task of the research: to find out the role of the interdisciplinary approach in the training of future educators of preschool education institutions and its influence on the process of formation of their professional competence.

The pedagogical experiment involved 309 students from 4 institutions of pedagogical education, from which the control $(2 \mathrm{KG}, \mathrm{n}=145)$ and experimental (2 $E G, n=164)$ groups were formed.

A comparative analysis was carried out between the indicators of the levels of formation of professional competence of future educators of preschool education institutions of the control and experimental groups at the beginning of the experimental study on their homogeneity; the levels of formation of this indicator of the control and experimental groups at the beginning (III year of study) and at the end of the experimental study (IV year of study) were assessed.

Methods. For realization of the purpose and tasks of research traditional (theoretical analysis and generalization of data of scientific and methodical literature: abstraction, systematization, comparison and comparison) and specific research methods were used (deductive, axiomatic, hypothetical-deductive, inductive methods - for definition of structure professional competence of future educators of preschool education institutions, characteristics of indicators and levels of its formation and to develop a diagnostic map for assessing the formation of professional competence of future educators of preschool education institutions, methods of descriptive statistics, methods of comparing nominal data.

Results. The most important stage of scientific analysis of the formation of professional competence of future educators of (PE) on the basis of interdisciplinary approach is a pedagogical experiment, which is one of the most effective ways to objectively test the validity of the research hypothesis. Theoretical analysis of the problem associated with the use of interdisciplinary approach to the formation of professional competence of future educators (PE), identification of factors, trends and contradictions determined the content and methodology of research and experimental work, as well as outlined key guidelines in its organization that meet the requirements pedagogical experiments $[1 ; 4 ; 6]$.

The pedagogical experiment, the purpose of which was to test the effectiveness of pedagogical conditions and the effectiveness of the structural and functional model of formation of professional competence of future educators of (PE) on the basis of an interdisciplinary approach, was conducted during 2017-2020.

To achieve this goal, the tasks were formulated, which were solved within the framework of achieving the targets of the study:

- to analyze the initial state of the researched problem in the theory and practice of psychological and pedagogical science, interdisciplinary researches;

- to organize the educational activities of future educators of (PE) on the basis of the developed structural and functional model of formation of professional competence of future educators of(PE); 
- to diagnose the formation of professional competence of future educators (PE) after graduation, using the completeness and adequacy of the selected criteriondiagnostic tools that reflect the degree of manifestation of each component (motivational, cognitive, procedural, personal) of the studied integrative professional and personal characteristics. sufficiently objectively judge the intensity and direction of change.

In general, the experimental work covered three stages: ascertaining, formative and final. The first stage involved the initial diagnosis (observational experiment) and analysis of the data. The result of this stage was the division of respondents into 2 groups: control and experimental. The second stage involved the organization and implementation of a formative experiment: the implementation of pedagogical conditions and structural and functional model of the formation of professional competence of future educators (PE) on the basis of an interdisciplinary approach. The third stage included re-diagnosis (final experiment) after the implementation of pedagogical conditions and the designed structural and functional model of formation of professional competence of future educators of (PE) on the basis of an interdisciplinary approach. Also, the final stage involved comparing the results of primary and re-diagnosis of respondents from both groups, conducting qualitative and quantitative analysis, as well as displaying a comparative analysis of data. At the last stage of the study, a statistical analysis of the results was performed.

The general direction of the experimental research was to identify the effectiveness of the implementation of pedagogical conditions for the formation of professional competence of future educators (PE) on the basis of an interdisciplinary approach. Empirical methods (pedagogical observation, testing, questionnaires, conversation) and mathematical methods of processing results were used to perform the tasks of the formative experiment. The methods of mathematical statistics were used to generalize the measurement results, analyze them and correlate them with the probabilistic characteristics of the studied objects. Experimental testing of the effectiveness of pedagogical conditions and the effectiveness of the structuralfunctional model was conducted on the basis of four institutions of higher pedagogical education. The study involved 164 students studying in the areas of training "Preschool Education".

To test the effectiveness of the proposed pedagogical conditions, students were divided into control and experimental groups. Given that the division into groups was carried out randomly, there was a need to study the homogeneity of these groups. To do this, a diagnosis of the formation of levels of professional competence of future educators (PE) at the beginning of the experiment, the results of which are shown in table. 1 .

Table 1. Levels of formation of professional competence of future educators of (PE) at the beginning of the experiment

\begin{tabular}{|c|c|c|c|c|c|c|c|c|}
\hline \multirow{3}{*}{$\begin{array}{l}\text { Training } \\
\text { direction }\end{array}$} & \multirow{3}{*}{ Groups } & \multirow{3}{*}{$\begin{array}{l}\text { Number of } \\
\text { students }\end{array}$} & \multicolumn{6}{|c|}{ Levels of formation } \\
\hline & & & \multicolumn{2}{|c|}{ High } & \multicolumn{2}{|c|}{ Medium } & \multicolumn{2}{|c|}{ Low } \\
\hline & & & Abs. & $\%$ & Abs. & $\%$ & Abs. & $\%$ \\
\hline \multirow{2}{*}{$\begin{array}{l}\text { Pre-school } \\
\text { education }\end{array}$} & $\mathrm{E} \Gamma$ & 80 & 14 & 17,5 & 18 & 22,5 & 48 & 60,00 \\
\hline & КГ & 84 & 17 & 20,24 & 19 & 22,62 & 48 & 57,14 \\
\hline
\end{tabular}


According to the data presented in the table, the levels of formation of professional competence of future educators ZDO at the beginning of the experiment in the experimental and control groups do not have significant differences. It should be noted that in the control groups there was an even larger (by 2.86\%) number of students who are at high and medium level and a smaller (by $2.86 \%$ ) number of students at a low level of professional competence of future educators.

To verify the reliability of the detected minor differences, which indicate the homogeneity of the control and experimental groups, the nonparametric Pearson's criterion (chi-square) was used [3, p. 286]. Due to the different number of students in the control and experimental groups, the distribution of relative frequencies was used, the sum of which should always be equal to $100 \%$. Our distribution meets the main requirement of Pearson's criterion - the frequency of the interval is not less than 30. We formulate the null hypothesis as follows: the experimental and control groups are chosen homogeneous, they do not differ significantly in success. Considering the three levels (high, medium, low), we note that there are degrees of freedom. To

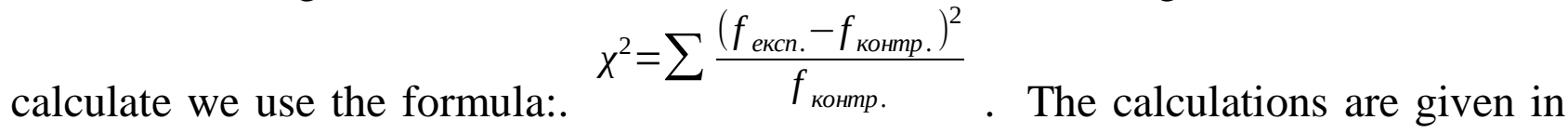
table. 2.

\section{Table 2. Calculation -criterion for the levels of formation of professional competence of future educators $\mathrm{PE}$ at the beginning of the experiment}

\begin{tabular}{|c|c|c|c|c|c|c|c|}
\hline Level & $\begin{array}{l}\text { Frequency } \\
f_{\text {ексn. }}\end{array}$ & $\begin{array}{l}\text { Frequency } \\
f_{\text {контр. }}\end{array}$ & 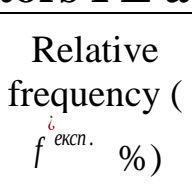 & $\begin{array}{c}\text { Relative } \\
\text { frequency ( } \\
f^{\text {' контр. } \%)}\end{array}$ & $\begin{array}{l}\left(f^{i} \text { експ. }-\right. \\
\left.f^{i} \text { контр. }\right)\end{array}$ & $\begin{array}{l}\left(f^{b \text { експ. }}-\right. \\
\left.f^{i} \text { контр. }\right)^{2}\end{array}$ & $\begin{array}{l}\left(\left(f^{i} \text { експ. }-\right.\right. \\
\left.\left.f^{i} \text { контр. }\right)^{2}\right) l \\
f^{i} \text { контр. }\end{array}$ \\
\hline High & 14 & 17 & 17,5 & 20,24 & $-2,74$ & 7,5076 & 0,37092 \\
\hline Medium & 18 & 19 & 22,5 & 22,62 & $-0,12$ & 0,0144 & 0,000636 \\
\hline Low & 48 & 48 & 60,00 & 57,14 & 2,86 & 8,1796 & 0,14315 \\
\hline Sum & 80 & 84 & 100 & 100 & 0 & & 0,51 \\
\hline
\end{tabular}

Found 0.51. From the table of critical values of the criterion [3, p. 288] received a tabular value of $95 \%$ probability: 5.99. Since, the null hypothesis is accepted: experimental and control groups do not differ in the level of formation of professional competence of future educators of PE. The value obtained is not large enough, which indicates that the differences between the distribution of EC and CG in terms of indicators are insignificant.

Thus, the results of the analysis conducted at the beginning of the formative experiment indicate that students of control and experimental groups have approximately the same level of formation of professional competence of future educators of PE.

The next stage of the formative experiment was the introduction into the educational process of students of experimental groups of a set of pedagogical conditions and structural-functional model of formation of professional competence of future educators of PE on the basis of interdisciplinary approach. To identify the effectiveness of the proposed pedagogical conditions, the levels of professional competence of future educators of PE were checked. In the interests of the 
experimental study, a comparison of the levels of professional competence of future educators of PE in students of CG and EG, the composition of which changed to take into account students who dropped out (73 students entered the EG, 72 students majoring in "Preschool Education").

The results of the diagnosis demonstrate the dynamics of changes observed between the initial and final results of the study in the experimental and control groups (Table 3 ).

Table 3. Levels of formation of professional competence of future educators of

PE

\begin{tabular}{|c|c|c|c|c|c|c|c|c|c|}
\hline \multirow{3}{*}{$\begin{array}{l}\text { Training } \\
\text { direction }\end{array}$} & \multirow{3}{*}{ Groups } & \multirow{3}{*}{$\begin{array}{l}\text { Number of } \\
\text { students }\end{array}$} & \multirow{3}{*}{$\begin{array}{l}\text { Stages of the } \\
\text { experiment }\end{array}$} & \multicolumn{6}{|c|}{ Levels of formation } \\
\hline & & & & \multicolumn{2}{|c|}{ High } & \multicolumn{2}{|c|}{ Medium } & \multicolumn{2}{|c|}{ Low } \\
\hline & & & & Abs. & $\%$ & Abs. & $\%$ & $\begin{array}{c}\mathrm{Ab} \\
\mathrm{s}\end{array}$ & $\%$ \\
\hline \multirow{4}{*}{$\begin{array}{l}\text { Pre-school } \\
\text { education }\end{array}$} & \multirow{2}{*}{$\mathrm{E} \Gamma$} & 80 & start & 14 & 17,5 & 18 & 22,5 & 48 & 60,00 \\
\hline & & 72 & finish & 25 & 34,72 & 33 & 45,83 & 14 & $\mathbf{1 9 , 4 5}$ \\
\hline & \multirow{2}{*}{ КГ } & 84 & start & 17 & 20,23 & 19 & 22,6 & 48 & 57,13 \\
\hline & & 73 & finish & 18 & 24,66 & 25 & 34,25 & 30 & 41,09 \\
\hline
\end{tabular}

Qualitative indicators (the percentage of students with high and medium levels of professional competence of future educators PE) at the end of the formative experiment in the experimental groups is $80.55 \%$, while in the control $-58.91 \%$. The high level of formation of professional competence of future educators of PE in the experimental groups increased by $17.22 \%$, while in the control groups only - by $4.43 \%$. The difference between the average level in the control and experimental groups is $11.58 \%$ in favor of the latter. Comparison of the results at the beginning and end of the experimental activity indicates the presence of positive dynamics in the experimental groups. This increase in the level of professional competence of future educators of $\mathrm{PE}$ in experimental groups is explained by the effectiveness of the formative experiment.

To determine the probability of the obtained results, we use the Pearson coefficient [3, p. 286], calculating $\mathrm{x}^{2}$ for the proposed criterion (Table 4).

Table 4. Calculation of $x^{2}$ to determine the levels of formation of professional competence of future educators $P E$

\begin{tabular}{|l|c|c|c|c|c|c|c|}
\hline \multicolumn{1}{|c|}{ Level } & $\begin{array}{c}\text { Frequency } \\
\mathrm{f}^{1}\end{array}$ & $\begin{array}{c}\text { Frequency } \\
\mathrm{f}^{2}\end{array}$ & $\begin{array}{c}\text { Relative } \\
\text { frequency } \\
\left(\mathrm{f}^{*} \%\right)\end{array}$ & $\begin{array}{c}\text { Relative } \\
\text { frequency } \\
\left(\mathrm{f}^{*} \%\right)\end{array}$ & $\left(\mathrm{f}^{*}-\mathrm{f}^{* 2}.\right)$ & $\left(\mathrm{f}^{*}-\mathrm{f}^{*}\right)^{2}$ & $\left(\left(\mathrm{f}^{*}-\mathrm{f}^{*} .\right)^{2}\right) / \mathrm{f}^{*}$. \\
\hline High & 25 & 18 & 34,72 & 24,66 & 10,06 & 101,2036 & 4,10395 \\
\hline Medium & 33 & 25 & 45,83 & 34,25 & 11,58 & 134,0964 & 3,91522 \\
\hline Low & 14 & 30 & 19,45 & 41,09 & $-21,64$ & 468,2896 & 11,39668 \\
\hline Sum & 72 & 73 & 100 & 100 & 0 & & $\mathbf{1 9 , 4 2}$ \\
\hline
\end{tabular}

The number of intervals $n=3$ (levels of formation), so the degree of freedom is $\mathrm{s}=\mathrm{n}-1=2$. According to the table $\mathrm{x} 2$ - Pearson's criterion, we establish that the corresponding 2 degree of freedom critical value is $x 2$ crit. $=5.99$ [3, p. 288]. Since we found $\mathrm{x} 2 \mathrm{exp} .=19.42$ more than $\mathrm{x} 2$ crit., The null hypothesis is rejected, which means a difference in the learning outcomes of students in the experimental group. This is evidence of the effectiveness of the proposed pedagogical conditions. 
For clarity of change of levels of formation of professional competence of future educators of ZDO in experimental and control groups after carrying out formative experiment is resulted in fig. 1.

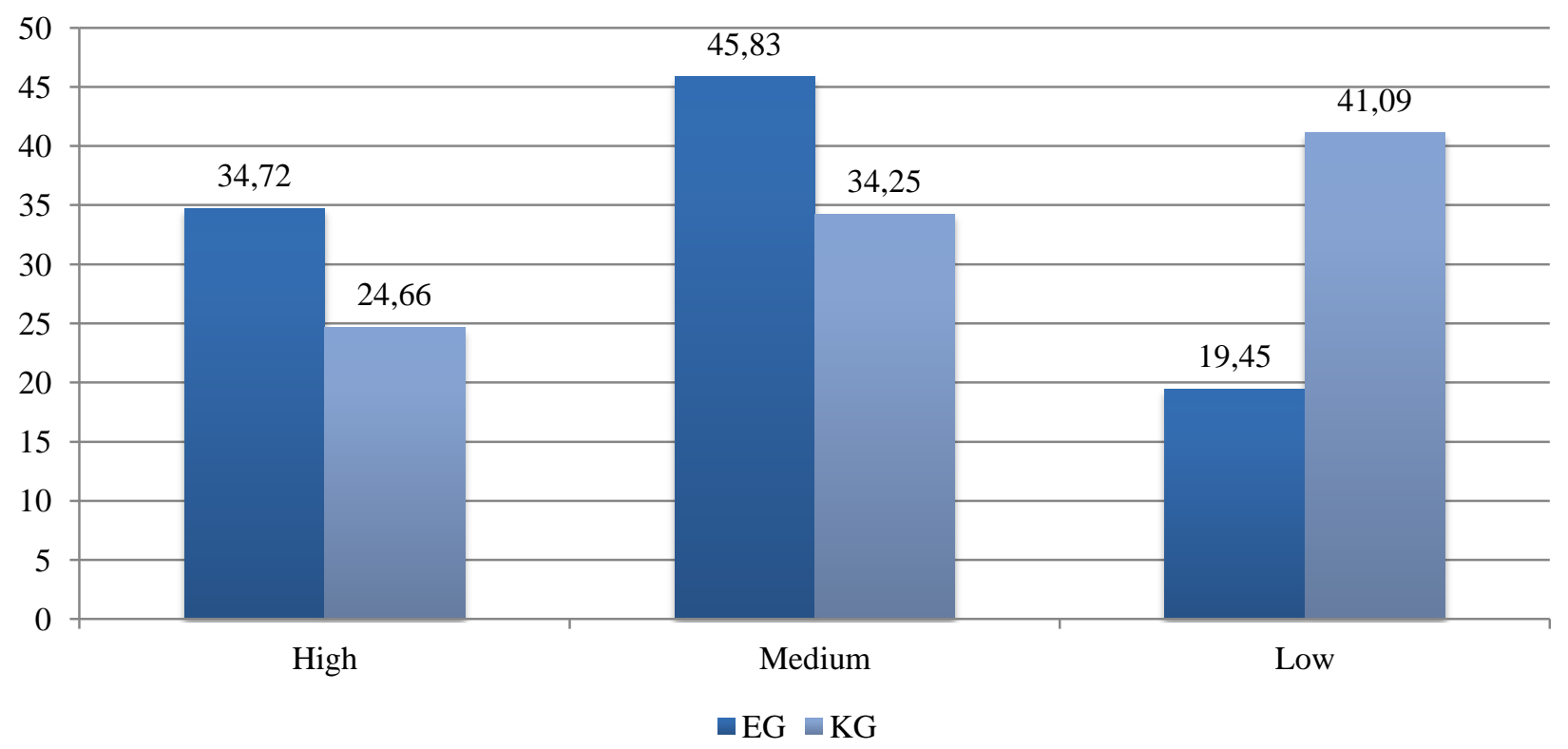

Figure. 1. Levels of formation of professional competence of future educators of $\mathrm{PE}$ at the end of the experiment in EG and KG

Discussion. Thus, on the basis of the obtained experimental data we can conclude that the pedagogical conditions for the formation of professional competence of future educators PE, which were implemented on the basis of structural and functional model, increase the levels of professional competence of future educators PE. The results of the experimental study are confirmed by reliable indicators, which are verified using the methods of mathematical statistics.

Conclusion. Thus, pedagogical monitoring of training of future educators of preschool education on the basis of interdisciplinary approach is carried out using a set of diagnostic techniques that allow to study the course and results of gradual development of all components of professional competence and observe the dynamics of its formation in students. The integrity and effectiveness of the criteriondiagnostic apparatus used to assess the level of professional competence is ensured by the gradual formation of its components according to their indicators, best accumulates individual diagnostics, including author's, and allows full reflection of the process of professional competence of future SMEs. training on the basis of an interdisciplinary approach.

We see further scientific research in the continuation of improving the professional training of future educators of preschool education institutions in order to comprehensively form their professional competence on the basis of an interdisciplinary approach.

\section{References:}

1. Honcharov S. M., Huryn V. A., (2010), Metody ta tekhnolohii navchannia v kredytno-transfernii systemi orhanizatsii navchalnoho protsesu: navch.-metod [Methods and technologies of teaching in the credittransfer system of the educational process: teaching method. Way], Rivne, 451 s. [in Ukraine] 
2. Kalichak Yu., (2018), Formuvannia kompetentnosti vykhovateliv zakladiv doshkilnoi osvity v protsesi profesiinoi pidhotovky [Formation of competence of educators of preschool education institutions in the process of professional training. Youth and the market], Molod i rynok, Vyp. 6 (161), S. 65-70.[in Ukraine] 3. Kyiveryalg A. A., (1980), Metodyi issledovaniy v professionalnoy pedagogike [Methods of research in professional pedagogy], Tallin, $334 \mathrm{~s}$. [in Russia]

4. Sysoieva S. O., Krystopchuk T. Ye. (2009). Pedahohichnyi eksperyment v naukovykh doslidzhennia neperervnoi profesiinoi osvity: navch.-metod. [Pedagogical experiment in scientific research of continuing professional education: teaching method. way], Lutsk, 460 s.[in Ukraine]

5. Solovova N. V., Suhankina N. V., Kalmyikova O. Yu.,(2020), Soderzhanie i struktura organizatsionnoupravlencheskoy kompetentnosti prepodavatelya vuz. [The content and structure of organizational and managerial competence of the university teacher], Otechestvennaya i zarubezhnaya pedagogika, № 1 (65), S. 33-46. [in Russia]

6. Surmin Yu. P., (2006), Maisternia vchenoho: pidruch. dlia naukovtsia [Scientist's workshop: textbook. for the scientist.), Kiev, 302 s.[in Ukraine]

Received: November 12, 2020

Approved: December 11, 2020 